\title{
МИКРОБИОЛОГИЧЕСКИЕ И ЭКОФИЗИОЛОГИЧЕСКИЕ ПАРАМЕТРЫ ДЕРНОВО-ПОДЗОЛИСТОЙ ПОЧВЫ ПРИ ДЛИТЕЛЬНОМ ПРИМЕНЕНИИ СОЛОМЫ И МИНЕРАЛЬНЫХ УДОБРЕНИЙ, ИХ СВЯЗЬ С УРОЖАЙНОСТЬЮ
}

\section{И.В. РУСАКОВА}

Экологизация применения удобрений в современном земледелии предусматривает интенсификацию использования биологических источников воспроизводства почвенного плодородия, в первую очередь биоресурсов агроценозов. Послеуборочные остатки сельскохозяйственных культур - один из существенных и легко возобновляемых биоресурсов. В связи с этим биологизированные ресурсосберегающие приемы и агротехнологии включают возврат послеуборочных остатков в почву без отчуждения с поля, что обеспечивает увеличение входа органического углерода, повышение биологического статуса почв, их плодородия и продуктивности. В нашей работе впервые показано, что в результате многолетнего (20 лет) внесения соломы в комбинации с минеральными удобрениями биологическое состояние дерново-подзолистой почвы становится более благоприятным, по ряду микробиологических показателей приближаясь к залежи, с превалированием аккумулятивных процессов накопления микробного и почвенного углерода, а также повышением урожайности. Цель исследования заключалась в оценке влияния многократного внесения соломы зерновых и зернобобовых культур в зернопропашном севообороте (раздельно и в сочетании с минеральными удобрениями) на показатели биологического состояния дерново-подзолистой почвы и урожайность однолетних трав. Исследования проводили в длительном полевом опыте (заложен в 1996 году) на опытном поле Всероссийского НИИ органических удобрений и торфа. Почва - дерново-подзолистая, севооборот - озимая пшеница, люпин (на зерно), картофель, ячмень, однолетние травы (люпин + овес). Схема опыта включала следующие варианты: без удобрений (контроль), минеральные удобрения (МУ, среднегодовая доза $\left.\mathrm{N}_{54} \mathrm{P}_{51} \mathrm{~K}_{57}\right)$, солома озимой пшеницы, люпина, ячменя (по 3 т/га), МУ + солома озимой пшеницы, люпина (по 3 т/га). По завершении 4-й ротации севооборота определяли показатели, характеризующие состав, структуру и метаболическую активность микробного сообщества исследуемой почвы: углерод микробной биомассы $\left(\mathrm{C}_{\text {мик. }}\right)$, численность и соотношение эколого-трофических групп микроорганизмов, базальное дыхание (БД), экофизиологические коэффициенты, общий органический углерод $\left(\mathrm{C}_{\text {орг. }}\right)$, углерод, экстрагируемый холодной и горячей водой, общий и щелочногидролизуемый азот. Также оценивали урожайность бобово-злаковых трав. Установлено, что многолетнее внесение соломы и МУ в зернопропашном севообороте значительно повлияло на микробную деятельность в ДПП. При ежегодном внесении МУ и удалении всех послеуборочных остатков поддерживалась высокая функциональная активность микроорганизмов, о чем свидетельствовали высокие значения БД и микробного метаболического коэффициента $\mathrm{qCO}_{2}$, однако, судя по низким величинам

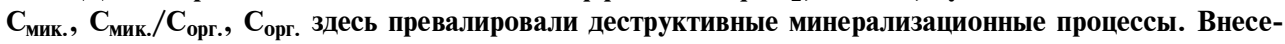
ние соломы без МУ в севообороте не оказало отрицательного влияния на биологические свойства и урожайность, что можно объяснить чередованием в севообороте разнокачественной по биохимическому составу соломы злаковых культур и люпина. Регулярная заделка соломы в комбинации со средними дозами МУ поддерживала сбалансированную обеспеченность микробного сообщества элементами питания и углеродом, способствовала снижению минерализационных процессов, накоплению в почве $\mathrm{C}_{\text {мик. }}$ и $\mathrm{C}_{\text {орг. }}$ Микробная биомасса тесно коррелировала с содержанием в почве общего $(r=0,94 ; \mathbf{p}<0,05)$ и легкоразлагаемого углерода $(r=0,89 ; \mathrm{p}<0.05)$ и азота $(r=0,95 ; \mathrm{p}<0,05)$, урожайность однолетних трав - с большинством определяемых в эксперименте показателей.

Ключевые слова: микробное сообщество, микробная биомасса, солома, минеральные удобрения, дерново-подзолистая почва.

Плодородие почв и его рациональное использование во многом определяется интенсивностью и направленностью биохимической деятельности микроорганизмов, осуществляющих деструкцию и минерализацию почвенного органического вещества (ПОВ). Почвенная микробная биомасса (МБ) - очень чувствительный пул ПОВ, и любое изменение в управлении агроэкосистемами отражается на структуре и содержании МБ гораздо быстрее, чем на содержании общего органического вещества (1-3).

Сельскохозяйственное использование земель, включающее регу- 
лярную механическую обработку почвы, применение различных агрохимикатов, ежегодное отчуждение большей части фитомассы, часто приводит к снижению запасов МБ, существенным нарушениям в ее структуре и функциях по сравнению с естественными экосистемами (4, 5). Неблагоприятное влияние сельскохозяйственного производства на микробиологическое качество почвы становится глобальной проблемой (6). В ряде исследований $(7,8)$ показано отрицательное влияние минеральных удобрений (МУ), в первую очередь азотных, на МБ, что объясняется подкислением, а также снижением запасов биологически доступного углерода.

Органическое вещество - основной ограничивающий фактор для микробной деятельности в пахотных почвах $(7,9,10)$. Методы управления агроэкосистемами и агротехнологии, обеспечивающие высокие темпы поступления экзогенного углерода в почву, в том числе за счет возврата послеуборочных растительных остатков (РО), которые служат трофическим и энергетическим источником для микроорганизмов (11), создают условия для сохранения и роста МБ. Так, возвращение соломы обеспечило более благоприятные микробиологические и биохимические характеристики почвы по сравнению с ее удалением $(12,13)$. В научной литературе также встречаются данные об отсутствии или негативном влиянии соломы зерновых культур на биологическую активность и эффективное плодородие почв (14). При этом мало известно о последствиях длительного применения соломы для микробного сообщества.

В нашей работе впервые показано, что в результате многолетнего (20 лет) внесения соломы в комбинации с минеральными удобрениями биологическое состояние дерново-подзолистой почвы становится более благоприятным, по ряду микробиологических показателей приближаясь к залежи, с превалированием аккумулятивных процессов накопления микробного и почвенного углерода, а также повышением урожайности.

Цель исследования заключалась в оценке влияния многократного внесения соломы зерновых и зернобобовых культур в зернопропашном севообороте (раздельно и в сочетании с минеральными удобрениями) на показатели биологического состояния дерново-подзолистой почвы и урожайность однолетних трав.

Методика. Исследования проводили в длительном полевом опыте (заложен в 1996 году) на опытном поле Всероссийского НИИ органических удобрений и торфа. Почва - дерново-подзолистая, севооборот озимая пшеница, люпин (на зерно), картофель, ячмень, однолетние травы

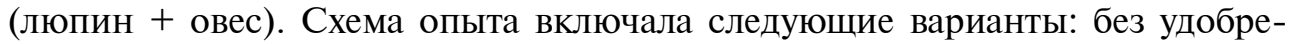
ний (контроль), МУ (среднегодовая доза $\mathrm{N}_{54} \mathrm{P}_{51} \mathrm{~K}_{57}$, внесение ежегодно перед посевом культур), солома озимой пшеницы, люпина, ячменя (по 3 т/га внесение осенью после уборки зерновых и зернобобовых культур), МУ + солома озимой пшеницы, люпина (по 3 т/га). Суммарно за 4 ротации севооборота в пахотный слой почвы было внесено 36 т/га соломы. Повторность в опыте во времени 2-кратная, в пространстве - 3-кратная; площадь делянок - 42-47 м². $^{2}$

Образцы почвы для анализов отбирали по окончании 4-й ротации севооборота (2016-2017 годы) тростевым буром (0-20 см) через 2 нед после уборки зеленой массы однолетних трав (люпин - сорт Кристалл, овес сорт Друг), готовили смешанные образцы из 20-30 индивидуальных проб с каждой делянки. В эти же сроки были взяты образцы почв пара и залежи (0-20 см), расположенных вблизи от пахотных почв и являющихся их генетическими аналогами. 
Определяли микробиологические и экофизиологические параметры, наиболее часто используемые в отечественных и зарубежных исследованиях $(7-9,15)$. Численность протеолитических микроорганизмов учитывали на мясопептонном агаре (МПА), амилолитических - на крахмалоаммиачном агаре (КАА), олиготрофных - на голодном агаре (ГА), олигонитрофилов - на безазотистой среде Эшби (16). Углерод микробной биомассы $\left(\mathrm{C}_{\text {мик. }}\right)$ оценивали регидратационным методом. Базальное дыхание (БД, мг $\mathrm{C}-\mathrm{CO}_{2} \cdot \mathrm{K \Gamma}^{-1}$ сухой почвы $\cdot$ сут $^{-1}$ ) определяли по скорости выделения $\mathrm{CO}_{2}$ почвой за 24 ч ее инкубации в лабораторных условиях при $22{ }^{\circ} \mathrm{C}$ и $60 \%$ полной влагоемкости, используя 0,5 н. $\mathrm{NaOH}$ для абсорбции $\mathrm{CO}_{2}$ с последующим титрованием 0,2 н. $\mathrm{HCl}$ с фенолфталеином. Коэффициенты олиготрофности ( $\left.\mathrm{K}_{\text {олигт. }}\right)$ и олигонитрофильности (К тывали соответственно как соотношение численности микроорганизмов на ГА и МПА (ГА/МПА), на среде Эшби и МПА (Эшби/МПА) (16); микробный фактор - как $\mathrm{C}_{\text {мик. }} / \mathrm{C}_{\text {орг. }}(\%)$; микробный метаболический коэффициент (удельное дыхание МБ) $\mathrm{qCO}_{2}-$ как отношение БД/С мик. $\left(\right.$ мг $\left.\mathrm{C}-\mathrm{CO}_{2} \cdot \mathrm{K \Gamma}^{-1} \cdot \mathrm{C}_{\text {мик. }}^{-1} \cdot \mathrm{ч}^{-1}\right)$. Наряду с биологическими показателями в почве определяли общий органический углерод $\left(\mathrm{C}_{\text {орг. }}\right)$ методом мокрого «сжигания» $\mathrm{K}_{2} \mathrm{Cr}_{2} \mathrm{O}_{7}+\mathrm{H}_{2} \mathrm{SO}_{4}$ (20 мин в сушильном шкафу при $160{ }^{\circ} \mathrm{C}$ ) с фотометрическим окончанием $(\lambda=590$ нм); углерод, экстрагируемый холодной водой $\left(\mathrm{C}_{\mathrm{B}}\right)$, в вытяжке после 3-минутного встряхивания (почва:вода $=1: 20)$; углерод, экстрагируемый горячей водой $\left(\mathrm{C}_{\text {эгв. }}\right)$, при 1-часовом кипячении почвенной суспензии (почва:вода $=1: 5$ ) на водяной бане $\left(80{ }^{\circ} \mathrm{C}\right)$ с последующим определением C в отфильтрованных вытяжках после выпаривания аликвот (аналогично анализу $\mathrm{C}_{\text {орг. }}$ ). Количество общего азота $\left(\mathrm{N}_{\text {общ. }}\right)$ измеряли фотометрическим методом «индофеноловой зелени»; щелочногидролизуемого ( $\mathrm{N}_{щ .}$. - по Корнфилду, с использованием 1,0 н. $\mathrm{NaOH}$ для гидролиза почвы в чашках Конвея (48 ч при $\left.28{ }^{\circ} \mathrm{C}\right), 2 \%$ раствора борной кислоты для поглощения выделяющегося $\mathrm{NH}_{3}$ и с последующим титрованием 0,02 н. $\mathrm{H}_{2} \mathrm{SO}_{4}$. Анализы выполняли в 3-6-кратной повторности; микробиологические - в свежих образцах в день отбора почвенных проб, химические - в воздушно-сухих с пересчетом данных на сухую почву.

Урожайность зеленой массы однолетних трав (люпино-овсяная смесь) учитывали по каждой делянке (учетная площадь - 16,8 м²) с пересчетом на сухое вещество.

Статистическую обработку данных проводили в программе STAT.EXE (Всероссийский НИИ удобрений и агропочвоведения им. Д.Н. Прянишникова, г. Москва) методом однофакторного дисперсионного анализа $(\mathrm{p}=0,05)$ с вычислением значений средних $(M)$ и стандартных отклонений $( \pm \mathrm{SD})$, используя $F$-критерий Фишера и НСР для оценки существенности разности между средними. Корреляционные коэффициенты рассчитывали в программе Statistica 6.0 («StatSoft, Inc.», США) (p $\leq 0,05)$.

Результаты. Растительные остатки служат комплексным питательным и энергетическим субстратом, основным источником биологически доступного углерода для гетеротрофных микроорганизмов $(9,11)$. Элементы питания, поступающие в почву с МУ, особенно азот, также важны для их активной жизнедеятельности.

За время проведения опыта в вариантах с внесением соломы в пахотный слой поступило 14,4 т/га органического углерода (около $90 \%$

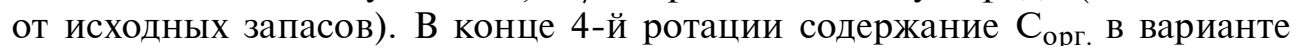
фон + солома составило $0,567 \%$, что было выше $(\mathrm{p}<0,05)$ по сравнению 
с контролем и внесением МУ соответственно в 1,22 и 1,13 раза (табл. 1).

Для поддержания микробной активности наиболее значимы легкоразлагаемые, быстро трансформирующиеся компоненты органического вещества (17). Водорастворимые органические соединения, представленные простыми аминокислотами, моносахарами, частично фульво- и гуминовыми кислотами, - наиболее доступный источник углерода для поч-

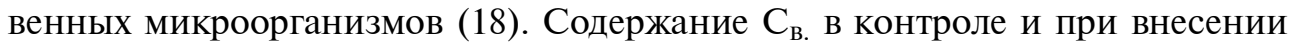
МУ было очень низким - соответственно 47,1 и 49,7 мг/кг почвы (сопо-

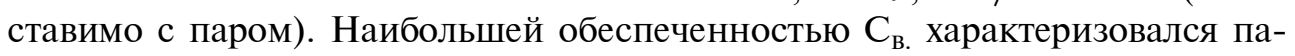
хотный слой с заделкой соломы - 59,4 мг/кг, что достоверно $(\mathrm{p}<0,05)$ превышало в 1,26 и 1,20 раза показатели в вариантах без удобрений и с

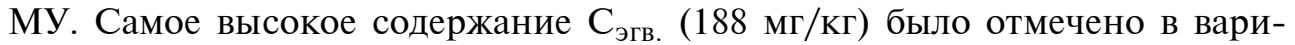
анте МУ + солома (в 1,20 и 1,08 раза выше, чем без внесения удобрений и с МУ), но различия по вариантам оказались несущественными (p > 0,05).

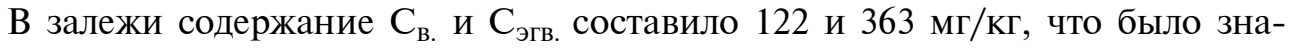
чимо (p < 0,05) выше (в 2,05 и 1,93 раза) даже в сравнении с максимальными значениями для этих фракций в почве севооборота (см. табл. 1).

1. Показатели биологического и агрохимического состояния дерново-подзолистой почвы при многократном внесении соломы и минеральных удобрений (МУ) $\mathbf{N}_{54} \mathbf{P}_{51} K_{57}$ в зернопропашном севообороте ( $M \pm \mathrm{SD}$; Владимирская обл., Судогодский р-н, 2016-2017 годы)

\begin{tabular}{l|c|c|c|c|c|c|c}
\hline \multicolumn{1}{c}{ Вариант } & \multicolumn{1}{c|}{$\mathrm{C}_{\text {орг. }}$} & $\mathrm{C}_{\text {мик. }}$ & $\mathrm{C}_{\text {в. }}$ & $\mathrm{C}_{\text {эгв. }}$ & БД & $\mathrm{C}_{\text {мик. }} / \mathrm{C}_{\text {орг. }}$ & $\mathrm{qCO}_{2}$ \\
\hline Без удобрений & $0,463 \pm 0,030^{\mathrm{a}}$ & $317 \pm 42^{\mathrm{a}}$ & $47,1 \pm 0,9^{\mathrm{a}}$ & $157 \pm 9^{\mathrm{a}}$ & $3,7 \pm 0,8^{\mathrm{a}}$ & 6,85 & 0,48 \\
МУ & $0,501 \pm 0,029^{\mathrm{b}}$ & $346 \pm 38^{\mathrm{a}}$ & $49,7 \pm 0,9^{\mathrm{a}}$ & $174 \pm 17^{\mathrm{a}}$ & $7,5 \pm 2,1^{\mathrm{bc}}$ & 6,91 & 0,90 \\
МУ + солома & $0,567 \pm 0,009^{\mathrm{c}}$ & $465 \pm 42^{\mathrm{b}}$ & $52,3 \pm 4,1^{\mathrm{ab}}$ & $188 \pm 9^{\mathrm{a}}$ & $8,1 \pm 1,4^{\mathrm{bc}}$ & 8,20 & 0,73 \\
Солома & $0,524 \pm 0,037 \mathrm{bc}$ & $383 \pm 29^{\mathrm{a}}$ & $59,4 \pm 5,6^{\mathrm{b}}$ & $182 \pm 29^{\mathrm{a}}$ & $6,7 \pm 1,2^{\mathrm{b}}$ & 7,31 & 0,73 \\
Пар & $0,400 \pm 0,008^{\mathrm{d}}$ & $187 \pm 12^{\mathrm{c}}$ & $48,1 \pm 3,1^{\mathrm{a}}$ & $116 \pm 11^{\mathrm{b}}$ & $4,2 \pm 0,1^{\mathrm{ab}}$ & 4,68 & 0,94 \\
Залежь & $0,778 \pm 0,052^{\mathrm{e}}$ & $609 \pm 68^{\mathrm{d}}$ & $122 \pm 8,8^{\mathrm{c}}$ & $363 \pm 26^{\mathrm{c}}$ & $9,2 \pm 1,5^{\mathrm{c}}$ & 7,83 & 0,63
\end{tabular}

$\overline{П р ~ и ~ м ~ е ~ ч ~ а ~ н ~ и ~ е . ~} \mathrm{C}_{\text {орг. }}-$ содержание общего углерода, \%; $\mathrm{C}_{\text {мик. }}-$ углерод микробной биомассы, мг/кг почвы; $\mathrm{C}_{\text {в. }}-$ углерод, экстрагируемый холодной водой, мг/кг почвы; $\mathrm{C}_{\text {эгв. }}-$ углерод, экстрагируемый горячей водой, мг/кг почвы; БД - базальное дыхание, мг $\mathrm{C}-\mathrm{CO}_{2} /$ кг почвы; $\mathrm{C}_{\text {мик. }} / \mathrm{C}_{\text {орг. }}-$ микробный фактор, \%; $\mathrm{qCO}_{2}-$ микробный метаболический коэффициент, мг $\mathrm{C}-\mathrm{CO}_{2} \cdot \mathrm{K \Gamma}^{-1} \cdot \mathrm{C}_{\text {мик. }}{ }^{-1} \cdot \mathrm{q}^{-1}$. Описание вариантов см. в разделе «Методика». Одинаковые буквенные индексы указывают на отсутствие статистически значимого различия ( $\mathrm{p}>0,05)$.

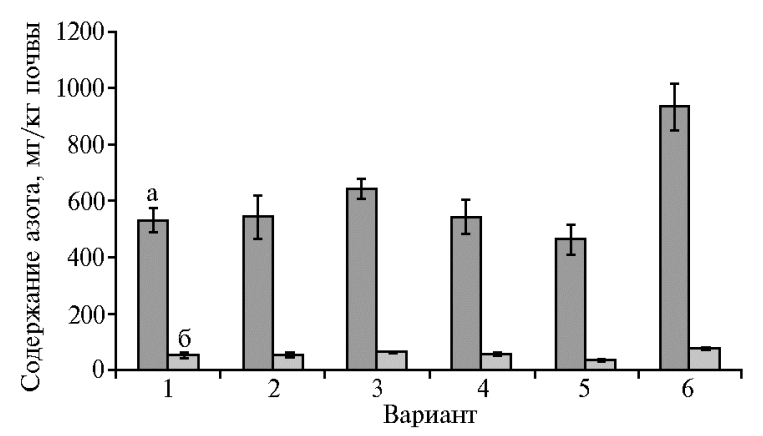

Рис. 1. Содержание общего (а) и легкогидролизуемого (б) азота в дерново-подзолистой почве при многократном внесении соломы и минеральных удобрений $\mathbf{N}_{54} \mathbf{P}_{51} \mathbf{K}_{57}$ в зернопропашном севообороте: 1 - без удобрений, $2-$ $\mathrm{N}_{54} \mathrm{P}_{51} \mathrm{~K}_{57}, 3-\mathrm{N}_{54} \mathrm{P}_{51} \mathrm{~K}_{57}+$ солома, $4-$ солома, $5-$ пар, 6 - залежь $(M \pm \mathrm{SD}$; Владимирской обл., Судогодский р-н, 2016-2017 годы). Описание вариантов см. в разделе «Методика». МУ. Однако в почве залежи анализируемые значения были существенно $(\mathrm{p}<0,05)$ выше: $\mathrm{N}_{\text {общ. }}-930$ мг/кг, $\mathrm{N}_{щ .}-75,6$ мг/кг почвы (рис. 1). 
Почвенная микробная биомасса - это живой компонент ПОВ, представленный в основном археями, бактериями и эукариотами, за исключением корней и животных (19). Измерение МБ широко применяется в качестве относительно простого средства оценки воздействия экологических и антропогенных изменений на почвенные микроорганизмы (20). По данным метаанализа данных литературы (414 наблюдений), содержание

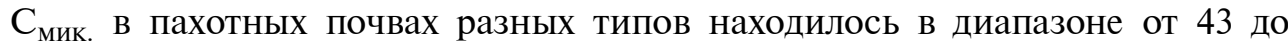
2155 мг/кг со средним значением 365 мг/кг почвы (7). В нашем исследовании минимальное содержание микробного углерода было зафиксировано в длительно парующей почве (187 мг/кг), максимальное - в залежи (609 мг/кг). В опыте максимальным значением $\mathrm{C}_{\text {мик. }}(465$ мг/кг), достоверно более высоким ( $<0,05)$, чем в остальных вариантах, характеризовалась почва пахотного слоя при внесении МУ и соломы. Это согласуется с результатами исследований $(3,10,21,22)$, в которых установлено увели-

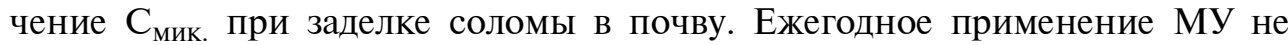

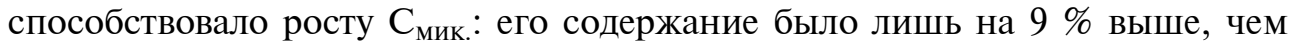
в контроле (см. табл. 1). Обобщение значительного массива данных в работе C. Kallenbach c coaвт. (7) показало, что в большинстве исследований также выявлено отрицательное влияние МУ на рост микробного сообщества, что объясняется их подкисляющим эффектом и дефицитом доступных источников углерода после первоначального повышения минерализационной деятельности. В литературе отмечается, что в постагрогенных почвах, переводимых в залежь, обеспечиваются условия, способствующие увеличению МБ в большей степени, чем в пахотных: отсутствие механических обработок, постоянное покрытие почвы растительностью, накопле-

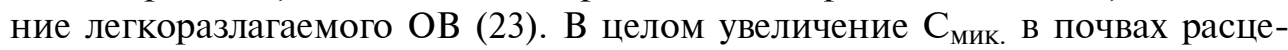
нивается как безусловно положительный факт, повышающий их биологический статус (20).

Отношение $\mathrm{C}_{\text {мик. }} / \mathrm{C}_{\text {орг. }}$ рассматривается как индикатор доступности

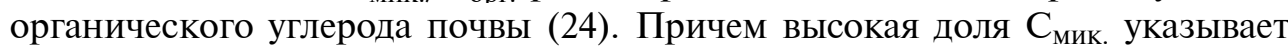
на закрепление органического углерода в МБ и свидетельствует о благоприятных условиях функционирования микробного сообщества. Низкое значение микробного фактора свидетельствует о снижении обеспеченности микрофлоры доступным органическим веществом. Соотношение

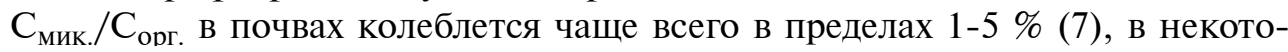
рых работах приводятся значения до $10 \%$ и выше (17). В нашем исследовании величина $\mathrm{C}_{\text {мик. }} / \mathrm{C}_{\text {орг. }}$ находилась в диапазоне от 6,85 (контроль) до 8,20\% (МУ + солома), что указывает на улучшение качества ПОВ, его доступности для микрофлоры и большую аккумуляцию углерода в МБ при многолетней заделке соломы в сочетании с МУ. В работах C.M. Kallenbach с соавт. (25) и А. Miltner с соавт. (26) также подчеркивается, что углерод, аккумулированный в МБ, вносит важный вклад в формирование гумусного фонда почв.

Микробное дыхание - интегральный параметр, который количественно отражает общую метаболическую активность гетеротрофной почвенной микрофлоры. Микробное продуцирование $\mathrm{CO}_{2}$, определенное в лабораторных условиях, следует оценивать как потенциальную активность МБ в оптимальных условиях температуры и влажности (15). Самое низкое значение БД (3,7 мг С-CO $2 /$ кг почвы) было зафиксировано нами в варианте, где культуры севооборота выращивались без удобрений, с использованием только базовых почвенных ресурсов. Судя по значениям БД, солома, внесенная отдельно, оказала существенное влияние на микробный 
метаболизм, повысив скорость дыхания в 1,8 раза $(\mathrm{p}<0,05)$. Наиболее активно и приблизительно с одинаковой скоростью минерализационные процессы протекали в вариантах МУ и МУ + солома, где скорость БД была в 2,03 и 2,20 раза выше ( $<0,05)$, чем в контроле (см. табл. 1).

Информативным показателем экофизиологического состояния микробного сообщества почвы может служить метаболический коэффициент $\mathrm{qCO}_{2}$, характеризующий эффективность использования субстрата микроорганизмами (27). Для пахотных почв $\mathrm{qCO}_{2}$ чаще всего варьирует в пределах от 0,5 до 2,0 мг С- $\mathrm{CO}_{2} \cdot \mathrm{K}^{-1} \cdot \mathrm{C}_{\text {мик. }}{ }^{-1} \cdot \mathrm{ч}^{-1}(28)$. Высокие значения указывают на весьма существенную потребность в источниках энергии или низкую эффективность использования органического субстрата. Величина $\mathrm{qCO}_{2}$ в наших опытах колебалась в зависимости от условий землепользования и применяемых удобрений от 0,48 мг $\mathrm{C}-\mathrm{CO}_{2} \cdot \mathrm{K \Gamma}^{-1} \cdot \mathrm{C}_{\text {мик. }}^{-1} \cdot \mathrm{ч}^{-1}$ в контроле до 0,90 в варианте с МУ и 0,94 мг $\mathrm{C}-\mathrm{CO}_{2} \cdot \mathrm{K \Gamma}^{-1} \cdot \mathrm{C}_{\text {мик. }}{ }^{-1} \cdot \mathrm{ч}^{-1}$ в почве пара (см. табл. 1). С точки зрения В. Zhang с соавт. (22), в экологическом плане высокий микробный метаболический коэффициент $\mathrm{qCO}_{2}$ отражает потребность гетеротрофов в углероде, и если углерод, который теряется при дыхании, не пополняется в почве, МБ уменьшается. При внесении соломы в комбинации с минеральными удобрениями удельное дыхание было в 1,5 раза выше, чем в контроле, но в 1,2 раза ниже $(\mathrm{p}<0,05)$ по сравнению с применением только МУ. То есть высокая обеспеченность микроорганизмов элементами питания при ежегодном внесении МУ без достаточного количества легкоразлагаемого ОВ не способствовала эффективному расходованию углерода, который терялся в большей степени при дыхании, чем на синтез биомассы, что, в свою очередь, снижало запасы углерода в почве. Низкое значение $\mathrm{qCO}_{2}$ в варианте без удобрений может свидетельствовать о более экономном расходовании углерода почвенной биотой в условиях отсутствия иных источников питания и энергии, кроме корне-пожнивных остатков культур севооборота. Высокое значение $\mathrm{qCO}_{2}$ $\left(0,94\right.$ мг $\left.\mathrm{C}-\mathrm{CO}_{2} \cdot \mathrm{K \Gamma}^{-1} \cdot \mathrm{C}_{\text {мик. }}{ }^{-1} \cdot \mathrm{ч}^{-1}\right)$ в почве пара, указывающее на потери углерода, можно объяснить стимулированием дыхательной активности почвы вследствие регулярных механических обработок.

2. Численность и соотношение микроорганизмов в сообществе дерново-подзолистой почвы при многократном внесения соломы и минеральных удобрений (MУ) $\mathbf{N}_{54} \mathbf{P}_{51} K_{57}$ в зернопропашном севообороте ( $M \pm \mathrm{SD}$; Владимирская обл., Судогодский р-н, 2016-2017 годы)

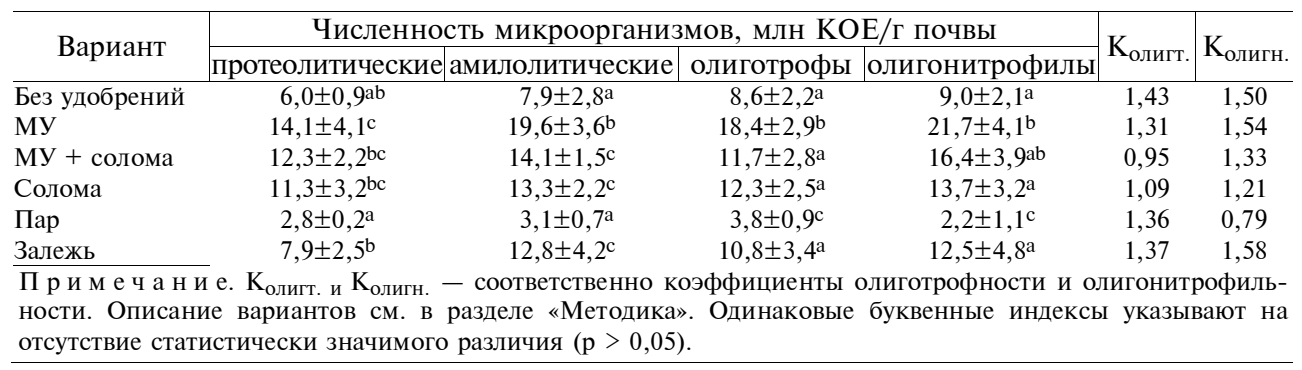

Численность и структура сообщества почвенных микроорганизмов имеют первостепенное значение для понимания происходящих в почве микробиологических процессов (4) и могут быть охарактеризованы количеством и соотношением микроорганизмов из различных физиологических или эколого-трофических групп. Нужно иметь в виду, что, учитывая численность той или иной группы, можно судить лишь о физиологиче- 
ском потенциале почвенных микроорганизмов, но не о его реализации в естественных условиях (29). Наиболее высокой численностью экологотрофических групп микроорганизмов характеризовались варианты МУ и МУ + солома. Однако более низкие $\mathrm{K}_{\text {олигт. }}\left(0,95\right.$ и 1,09) и $\mathrm{K}_{\text {олигн. }}(1,33$ и $1,21)$ в вариантах, где кроме МУ многократно вносили солому, свидетельствовали об относительном доминировании в этих условиях копиотрофной микрофлоры по сравнению с олиготрофной (табл. 2).

По данным А.Ю. Колодяжного с соавт. (30), заделка соломы в дерново-подзолистую почву способствовала увеличению численности копиотрофов (аммонифицирующих и амилолитических микроорганизмов) в 2,5 раза и снижению численности олиготрофов и педотрофов в 1,5 раза. Более высокие показатели абсолютной и относительной численности олиготрофов при ежегодном внесении МУ косвенно подтверждают превалирование деструктивных процессов разрушения гумуса в этом варианте. В целом в большинстве случаев присутствие остатков сельскохозяйственных культур в почве оказывало благоприятное воздействие на микробные сообщества $(6,7,13)$.

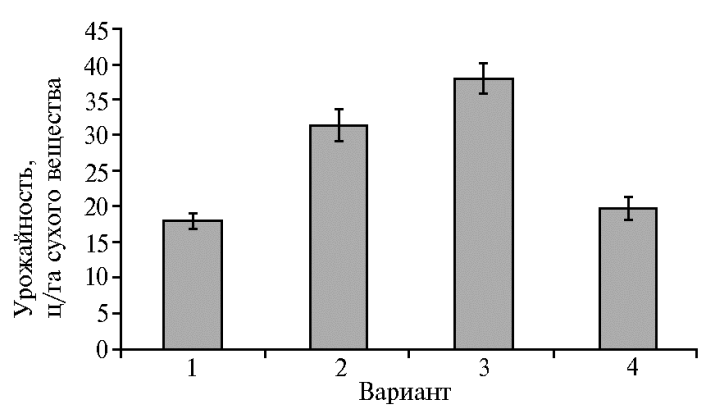

Рис. 2. Урожайность однолетних трав (люпин + овес) на дерново-подзолистой почве при многократном внесении соломы и минеральных удобрений $\mathbf{N}_{54} \mathbf{P}_{51} K_{57}$ в зернопропашном севообороте: 1 - без удобрений, $2-\mathrm{N}_{54} \mathrm{P}_{51} \mathrm{~K}_{57}, 3-\mathrm{N}_{54} \mathrm{P}_{51} \mathrm{~K}_{57}+$ солома, $4-$ солома $(M \pm \mathrm{SD} ; \quad$ Владимирская обл., Судогодский p-н, 2016-2017 годы). Описание вариантов см. в разделе «Методика».

Многолетнее внесение соломы в комбинации с МУ обеспечило максимальную урожайность бобово-злаковых трав 38,2 ц/га сухого вещества, что было существенно $(\mathrm{p}<0,05)$ выше по сравнению не только с не удобряемым вариантом, но и с фоном МУ (рис. 2). Это согласуется с данными исследований $(21,31)$, в которых также установлено положительное влияние соломы на плодородие почвы и урожайность культур.

В настоящей работе мы попытались найти количественную связь биологических показателей с общим содержанием $\mathrm{C}$ и $\mathrm{N}$, а также с легкометаболизируемыми фракциями. Величина урожайности однолетних трав значимо и положительно коррелировала $(\mathrm{p}<0,05)$ с показателями $\mathrm{C}_{\text {орг., }}, \mathrm{N}_{\text {обш. }}, \mathrm{C}_{\text {эгв. }}, \mathrm{C}_{\text {мик., }}$, $\mathrm{C}_{\text {мик. }} / \mathrm{C}_{\text {орг. }}$, численностью микроорганизмов на МПА $(r=0,88-0,93)$. Была выявлена достаточно тесная, однако несущественная отрицательная корреляционная зависимость между урожайностью и $\mathrm{K}_{\text {олигт. }}(r=-0,60)$. Микробный углерод достоверно $(\mathrm{p}<0,05)$ тесно коррелировал с $\mathrm{C}_{\text {орг. }}(r=0,94)$ и $\mathrm{N}_{\text {общ. }}(r=0,95)$, а также с содержанием $\mathrm{C}_{\text {эгв. }}(r=0,89)$, как это часто наблюдается в долгосрочных полевых экспериментах. Так, в длительном полевом опыте на суглинисто-лессовых почвах Германии в зернопропашном севообороте с применением минеральных и органических удобрений между $\mathrm{C}_{\text {мик. }}$ и $\mathrm{C}_{\text {орг. }}$, а также между $\mathrm{C}_{\text {мик. }}$ и $\mathrm{C}_{\text {эгв. }}$ обнаружена значительная положительная корреляция (соответственно $r=0,71$ и $r=0,65)$ (32).

Таким образом, многолетнее (12-кратное за 20-летний период проведения полевого опыта) внесение соломы и минеральных удобрений в зернопропашном севообороте значительно повлияло на микробную деятельность в дерново-подзолистой почве. При ежегодном внесении мине- 
ральных удобрений (МУ) и удалении всех послеуборочных остатков поддерживалась высокая функциональная активность микроорганизмов, о чем свидетельствуют высокие значения базального дыхания и микробного метаболического коэффициента $\mathrm{qCO}_{2}$. Однако, судя по низким величинам

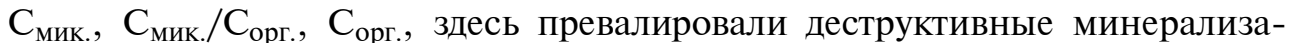
ционные процессы, не способствующие аккумуляции углерода в микробной биомассе и его накоплению в почве. Микроорганизмы в таких условиях менее эффективно используют органический субстрат, расходуя $\mathrm{C}$ на дыхание и увеличивая потери углерода из почвы. Внесение соломы без МУ в севообороте не оказало отрицательного влияния на биологические свойства и урожайность, что можно объяснить чередованием в севообороте разнокачественной по биохимическому составу соломы злаковых культур и люпина. Регулярная заделка соломы в комбинации со средними дозами минеральных удобрений поддерживала сбалансированную обеспеченность микробного сообщества элементами питания и углеродом, увеличивая аккумуляцию углерода в микробной биомассе. Значение $\mathrm{C}_{\text {мик. }} / \mathrm{C}_{\text {орг. }}$ в этом варианте было сопоставимо с таковым для залежной почвы. Полученные результаты подтверждают важность регулярного внесения в почву соломы зерновых и зернобобовых культур для поддержания благоприятного С-режима, обеспечения микробного сообщества биологически доступным органическим веществом и увеличения его биомассы.

\footnotetext{
Всероссийский НИИ органических удобрений и торфа -

Поступила в редакцию филиал ФГБНУ Верхневолжский аграрный научный центр, 14 мая 2019 года

601390 Россия, Владимирская обл., Судогодский р-н, д. Вяткино,

ул. Прянишникова, 2,

e-mail: rusakova.iv@yandex.ru $\bowtie$
}

Sel'skokhozyaistvennaya biologiya [Agricultural Biology], 2020, V. 55, № 1, pp. 153-162

\section{MICROBIOLOGICAL AND ECOPHYSIOLOGICAL PARAMETERS OF SOD-PODZOLIC SOIL UPON LONG-TERM APPLICATION OF STRAW AND MINERAL FERTILIZERS, THE CORRELATION WITH THE YIELD}

\section{I.V. Rusakova}

All-Russian Research Institute for Organic Fertilizers and Peat - Branch of Upper Volga Federal Agrarian Research Center, 2, ul. Pryanishnikova, Vyatkino, Sudogodskii Region, Vladimir Province, 601390 Russia, e-mail rusakova.iv@yandex.ru ( $\square$ corresponding author)

ORCID:

Rusakova I.V. orcid.org/0000-0002-5085-0578

The author declares no conflict of interests

Received May 14, 2019

doi: 10.15389/agrobiology.2020.1.153eng

Abstract

In modern agriculture, top priority is given to requirements for environmentally friendly application of fertilizers, providing for the intensification of use of biological sources of soil fertility recovery, primarily bioresources of farming ecosystems. One of significant, easily renewable biological resources is field residues of agricultural crops, which, according to many researchers, are the key to sustainable crop production and biosphere preservation. In this regard, one of main requirements for biologically based resource-saving methods and agrotechnologies is the returning of afterharvesting residues back into the soil without alienating the ones from the field, which ensures the enhancement of organic carbon input, improvement of biological status of soils, and their fertility and productivity, in general. A number of domestic and foreign papers prove the plant residues (PR), the structure of which consists of over $80 \%$ of straw of cereals and leguminous crops, to be important for the preservation of favorable microbiological state of the soil. However, there is uncertainty in the qualitative and quantitative evaluations of the effect of the straw on the soil microbial community since the PR burial that may have both positive and negative consequences, which is often noted 
when introducing straw with a wide $\mathrm{C}$ to $\mathrm{N}$ ratio. Experimental data available in the scientific literature were obtained mainly when conducting research in laboratory and short-term field experiments with single use of straw as a fertilizer. The data of long field experiments with the repeated introduction of straw in crop rotation are useful for a more complete understanding of the straw effect on the microbial community and the use of this knowledge for the development of effective methods for managing the plant residues. The purpose of this study was to assess the effect of long-term use of straw of cereals and leguminous crops and mineral fertilizers (MF), separately and in combination, on the biological status of sod-podzolic sandy-loam soil. The indicators characterizing the composition, structure and metabolic activity of the microbial community of sod-podzolic soil were determined at the end of the 4th rotation of the 5-course row-crop rotation in a long field experiment: microbial biomass $\left(\mathrm{C}_{\text {mic }}\right)$, microbial number and ratio of ecotrophic groups of microorganisms (ETGM), basal respiration (BR), and ecophysiological factors. It has been established that the return of afterharvesting residues in combination with medium doses of MF provides a balanced supply of nutrients and organic carbon to the microbial community and contributes to the reduction of mineralization processes and to the accumulation of $\mathrm{C}_{\text {mic }}$. The microbial biomass closely correlated with the content of total $(r=0.94, \mathrm{p}<0.05)$ and easily decomposable carbon $(r=0.89$, $\mathrm{p}<0.05)$ and nitrogen $(r=0.95, \mathrm{p}<0.05)$ in the soil, and the yield of annual grasses closely correlated with the most part of indicators being determined in the experiment.

Keywords: microbial community, microbial biomass, soil, straw, mineral fertilizers.

\section{REFEREN C ES}

1. Geisseler D., Scow K.M. Long-term effects of mineral fertilizers on soil microorganisms - a review. Soil Biology and Biochemistry, 2014, 75: 54-63 (doi: 10.1016/j.soilbio.2014.03.023).

2. Powlson D.S., Glendining M.J., Coleman K., Whitmore A.P. Implications for soil properties of removing cereal straw: results from long-term studies 1. Agronomy Journal, 2011, 103: 279-287 (doi: 10.2134/agronj2010.0146s).

3. Xu M., Lou Y., Sun X., Wang W., Baniyamuddin B., Zhao K. Soil organic carbon active fractions as early indicators for total carbon change under straw incorporation. Biology and Fertility of Soils, 2011, 47(7): 745-752 (doi: 10.1007/00374-011-0579-8).

4. Dobrovol'skaya T.G., Zvyagintsev D.G., Chernov I.Yu., Golovchenko A.V., Zenova G.M., Lysak L.V., Manucharova N.A., Marfenina O.E., Polyanskaya L.M., Stepanov A.L., Umarov M.M. Pochvovedenie, 2015, 9: 1087-1096 (doi: 10.7868/S0032180X15) (in Russ.).

5. Ceja-Navarro J.A., Rivera-Orduña F.N., Patiño-Zúñiga L., Vila-Sanjurjo A., Crossa J., Govaerts B., Dendooven L. Phylogenetic and multivariate analyses to determine the effects of different tillage and residue management practices on soil bacterial communities. Applied and Environmental Microbiology, 2010, 76(11): 3685-3691 (doi: 10.1128/AEM.02726-09).

6. Lal R. Restoring soil quality to mitigate soil degradation. Sustainability, 2015, 7(5): 5875-5895 (doi: 10.3390/su7055875).

7. Kallenbach C., Grandy A.S. Controls over soil microbial biomass responses to carbon amendments in agricultural systems: a meta-analysis. Agriculture, Ecosystems \& Environment, 2011, 144(1): 241-252 (doi: 10.1016/j.agee.2011.08.020).

8. Malý S., Královec J., Hampel D. Effects of long-term mineral fertilization on microbial biomass, microbial activity, and the presence of $r$ - and $K$-strategists in soil. Biology and Fertility of Soils, 2009, 45: 753-760 (doi: 10.1007/s00374-009-0388-5).

9. Juan L.I., Li Y.T., Yang X.D., Zhang J.J., Lin Z.A., Zhao B.Q. Microbial community structure and functional metabolic diversity are associated with organic carbon availability in an agricultural soil. Journal of Integrative Agriculture, 2015, 14(12): 2500-2511 (doi: 10.1016/S20953119(15)61229-1).

10. Lemtiri A., Degrune F., Barbieux S., Hiel M.P., Chélin M., Parvin N., Vandenbol M., Francis F., Colinet G. Crop residue management in arable cropping systems under temperate climate. Part 1: Soil biological and chemical (phosphorus and nitrogen) properties. a review. Biotechnologie, Agronomie, Societe, and Environment, 2016, 20(S1): 236-244 (doi: 10.25518/17804507.13015).

11. Kuzyakov Y., Blagodatskaya E. Microbial hotspots and hot moments in soil: concept \& review. Soil Biology and Biochemistry, 2015, 83: 184-199 (doi: 10.1016/j.soilbio.2015.01.025).

12. Chen Y., Xin L., Liu J., Yuan M., Liu S., Jiang W., Chen J. Changes in bacterial community of soil induced by long-term straw returning. Scientia Agricola, 2017, 74(5): 349-356 (doi: 10.1590/1678-992x-2016-0025).

13. Degrune F. Assessing microbial diversity changes associated with different tillage and crop residue managements: study case in a loamy soil. Doctoral dissertation. Université de Liège, Liège, Belgique, 2017.

14. Lazarev A.P., Abrashin Yu.I. Pochvovedenie, 2000, 10: 1266-1271 (in Russ.). 
15. Anan'eva N.D., Sus'yan E.A., Ryzhova I.M., Bocharnikova E.O., Stol'nikova E.V. Pochvovedenie, 2009, 9: 1108-1116 (in Russ.).

16. Titova V.I., Kozlov A.V. Metody otsenki funktsionirovaniya mikrobotsenoza pochvy, uchastvuyushchego $v$ transformatsii organicheskogo veshchestva [Methods for assessing the functioning of soil microbiocenosis involved in the transformation of organic matter]. Nizhnii Novgorod, 2012 (in Russ.).

17. Semenov V.M., Tulina A.S. Agrokhimiya, 2011, 12: 53-63 (in Russ.).

18. Semenov V.M., Kogut B.M. Pochvennoe organicheskoe veshchestvo [Soil organic matter]. Moscow, 2015 (in Russ.).

19. Ottow J.C.G. Funktionen und Quantifizierung der mikrobiellen Biomasse in Böden. In: Mikrobiologie von Böden. Springer, Berlin, Heidelberg, 2011: 29-53 (doi: 10.1007/978-3-64200824-5_2).

20. Gonzalez-Quiñones V., Stockdale E.A., Banning N.C., Hoyle F.C., Sawada Y., Wherrett A.D., Jones D.L., Murphy D.V. Soil microbial biomass - interpretation and consideration for soil monitoring. Soil Research, 2011, 49: 287-304 (doi: 10.1071/SR10203).

21. Zhao X., Yuan G., Wang H., Lu D., Chen X., Zhou J. Effects of full straw incorporation on soil fertility and crop yield in rice-wheat rotation for silty clay loamy cropland. Agronomy, 2019, 9(3): 133 (doi: 10.3390/agronomy9030133).

22. Zhang B., Gao Q., Xu S., Ma L., Tian C. Long-term effect of residue return and fertilization on microbial biomass and community composition of a clay loam soil. Journal of Agricultural Science, 2016, 154(6): 1051-1061 (doi: 10.1017/S0021859615001008).

23. Polyanskaya L.M., Sukhanova N.I., Chakmazyan K.V., Zvyagintsev D.G. Pochvovedenie, 2012, 7: 792-798 (in Russ.).

24. Wani S.A., Wani M.A., Sheikh A.A., Chand S. Microbiological-indicators with potential for evaluating soil quality. International Journal of Current Microbiology and Applied Sciences, 2017, 6(2): 831-839 (doi: 10.20546/ijcmas.2017.602.093).

25. Kallenbach C.M., Grandy A.S., Frey S.D., Diefendorf A.F. Microbial physiology and necromass regulate agricultural soil carbon accumulation. Soil Biology and Biochemistry, 2015, 91: 279-290 (doi: 10.1016/j.soilbio.2015.09.005).

26. Miltner A., Bombach P., Schmidt-Brücken B., Kästner M. SOM genesis: microbial biomass as a significant source. Biogeochemistry, 2012, 111(1-3): 41-55 (doi: 10.1007/s10533-011-9658-z).

27. Anderson T.-H., Domsch K.H. Soil microbial biomass: the eco-physiological approach. Soil Biology and Biochemistry, 2010, 42(12): 2039-2043 (doi: 10.1016/j.soilbio.2010.06.026).

28. Anderson T.-H. Microbial eco-physiological indicators to access soil quality. Agriculture, Ecosystems \& Environment, 2003, 98(1-3): 285-293 (doi: 10.1016/S0167-8809(03)00088-4).

29. Kruglov Yu.V. Microbial community of soil: physiological diversity patterns and assessment (review). Sel'skokhozyaistvennaya biologiya [Agricultural Biology], 2016, 51(1): 46-59 (doi: 10.15389/agrobiology.2016.1.46eng).

30. Kolodyazhnyi A.Yu., Patyka N.V., Orlova O.V. Zbalansovane prirodokoristuvannya, 2014, 2: 28 33 (in Russ.).

31. Hiel M.P., Barbieux S., Pierreux J., Olivier C., Lobet G., Roisin C., Garré S., Colinet G., Bodson B., Dumont B. Impact of crop residue management on crop production and soil chemistry after seven years of crop rotation in temperate climate, loamy soils. PeerJ, 2018, 6: e4836 (doi: 10.7717/peerj.4836).

32. Francioli D., Schulz E., Lentendu G., Wubet T., Buscot F., Reitz T. Mineral vs. organic amendments: microbial community structure, activity and abundance of agriculturally relevant microbes are driven by long-term fertilization strategies. Frontiers in Microbiology, 2016, 7: 1446 (doi: 10.3389/fmicb.2016.01446). 